dents and discuss professional careers in political science and submit to APSA the names of promising minority candidates whom they have pre-screened. (2) Attend the Minority Identification Project Breakfast for core graduate schools at the APSA Annual Conference. The faculty member acting as primary contact for the Project is asked to attend the APSA-hosted breakfast. (3) Contribute financially to the Project by purchasing mailing labels for an annual fee, currently, of $\$ 100$. (4) Actively recruit students identified by the Project. For these students they should:

a. invite/solicit applications from these students.

b. be willing to waive application fees.

c. offer full funding/fellowships for the students whom they accept.

Any Ph.D. program interested in participating and willing to meet the above requirements may request to become a core school. Please contact Jun Yin at jyin@apsanet.org.

\section{APSA Announces 1998-99 Minority Graduate Student Fellows}

APSA has named four Minority Graduate Fellows for 1998-99.

These students were chosen out of a highly impressive pool of diverse candidates representing the best schools throughout the country.

Three funded Fellows include Luz Inéz Gómez (Latina) of the University of California, Berkeley; Kimberly Clark (African American) of Rutgers University; and Temita Davis (African American) of North Carolina A \& T University.

One non-funded Fellow, Brandy Faulkner of Averett College was named as well. These Fellows, both funded and nonfunded, typically receive full support from universities as a result of their status as APSA Fellows. Many departments eagerly await the selection of Fellows in early December.

APSA Minority Fellowships were established to increase the number of minorities with doctoral degrees in political science. Fellowships are

\section{S I T E S E E I N G Political Science on the Web}

The World Wide Web hosts a wide range of information sources in political science, from governement sites to compilations offered by individual scholars. Among this growing selection of sites are those developed by the Organized Sections of the APSA. With concentration on a particular subfield, these sites provide scholars with access to the latest research in the field - through database archives, conference papers, and detailed bibliographies - to teaching materials that include syllabi, classroom excerices, and comments shared by colleagues in the profession. Below you will find a listing of those Sections maintaining web sites at this time.

\section{Law and Courts}

www. artsci.wustl.edu/ polisci/lawcourt.htm

\section{Public Policy}

www.fsu.edu/ spap/orgs/apsa.html

\section{Public Administration}

www.apsanet.org/ pubadmin

\section{Conflict Processes}

wizard.ucr.edu/cps/cps.html

Presidency Research
sunsite.unc.edu/lia/prgnet

\section{Political Methodology}

wizard.ucr.edu/polmeth/polmeth.html

\section{Religion and Politics}

www.gac.edu/Academics/poli-sci/relpol/r\&p.html

\section{Urban Politics}

thecity.sfsu.edu/ urbanpol

Science, Technology and Environmental Politics www2.ncsu.edu/ncsu/chass/mds/steps.html

\section{Women and Politics}

www.apsanet.org/ wpol

Foundations of Political Theory

www.apsanet.org/ theory

\section{Computers and Multimedia}

www.apsanet.org/ $\sim \mathrm{cms}$

\section{State Politics and Policy}

www.apsanet.org/ - state

\section{Politics and History}

www.sscnet.ucla.edu/polisci/apsa/index.html

\section{Domestic Sources of Foreign Policy}

www.apsanet.org/ $\sim \mathrm{dsfp}$

Race, Ethnicity and Politics

www.providence.edu/polisci/rep 
open to outstanding Native Americans, African Americans, and Latino(a)s planning to enroll in a doctoral program in the coming academic year. Funded fellowships are generally awarded only to students who are about to enter graduate school. Fellowships are not designed for advanced graduate students. Each year the application deadline falls on November 1 .

For more information, call or write APSA headquarters or visit the APSA web site at www.apsanet.org.

\section{Forty-Fifth Class of Congressional Fellows Begins 1997-98 Program}

As this year's class of 44 Congressional Fellows completed their orientation, they began an interviewing process occurring in a Congress that had undergone considerable turnover. Fellows divided their attention between offices which had long provided a solid learning experience for previous Fellows with the offices of Senators and Representatives who this year have for the first time hosted an APSA Congressional Fellow.

Among the veteran congressional offices again hosting a Congressional Fellow are: Senators Max S. Baucus (D-MT), Sam Brownback (R-KS), Alfonse D'Amato (R-NY), Richard Durbin (D-IL), James Jefford (RVT)'s Labor Committee, Edward Kennedy (D-MA)'s Judiciary Committee, Frank Lautenberg (D-NJ), and APSA Congressional Fellowship Program Advisory Committee member Richard Lugar (R-IN). Among those Senators or committees accepting Congressional Fellows for the first time include Senate Majority Leader Trent Lott (R-MS), Senator Pete Domenici (R-NM)'s Budget Committee, Senator John McCain (R-AZ), and Senator Olympia Snow (R-ME).

Fellows' assignments on the House side include long-time CFP supporters: Representatives Howard L. Berman (D-CA), APSA Congressional Fellowship Program Advisory Committee member David Price (DNC), Robert Ehrlich (R-MD), Sander Levin (D-MI), and Karen
Thurman (D-FL). Among Members of the House accepting their first Congressional Fellows were: Representatives Doug Bereuter (R-NE), Corrine Brown (D-FL), Michael Castle (R-DE), J. Dennis Hastert (R-IL), and Christopher Shays (RCT).

Senator Richard Lugar's observation about the APSA Congressional Fellows appears to be winning new adherents: "I am impressed by the skill and enthusiasm the Fellows display and I know of few other Washington mid-career programs whose standards for awarding fellowships come close to those set by the American Political Science Association."

Of special note was the Congressional Fellows' appreciation to our major funding benefactors including Program Advisory Board members Eugene Eidenberg (The Carlyle Group) and Gerald Kovach, representing the MCI Communications Corporation whose significant endowment provides a number of $\$ 30,000$ annual stipends for political science and journalist Fellows, and Advisory Committee member Robert Merry of Congressional Quarterly, Inc. which provides the Fellows with year-long subscriptions to Congressional Quarterly Weekly Reports and a reduced price on Politics in America.

For many Fellows the new world of networking became an important reality in the early weeks of the 1997-98 CFP year. This involved building new contacts among congressional staff during the interview process and, of particular importance, drawing upon the expertise and program loyalty among the some 1500 former Congressional Fellows, many of whom are scattered throughout the Washington, D.C. metropolitan area and who offered time and candid advice. One tangible example is the decision among the political scientists and international Fellows to collaborate on several publications this year including an article for $P S$.

\section{Census 2000 Update: Reporting Rules for Race and Ethnicity Set}

As reported in the October 30 , 1997 issue of the Federal Register, the Office of Management and Budget has adopted new rules for the collection of race and ethnicity information on government forms, including census forms.

According to the new rules, respondents will be allowed to check more than one category for "Race" and only one category for "Ethnicity." The choices for "Race" will be American Indian or Alaska Native, Asian, Black or African American, Native Hawaiian or Other Pacific Islander, and White. For "Ethnicity," respondents may choose either Hispanic or Latino or Not Hispanic or Latino. In announcing the new reporting rules and categories, OMB made it clear that "the categories represent a social-political construct designed for collecting data on the race and ethnicity of broad population groups in this country, and are not anthropologically or scientifically based."

Guidelines for tabulating data collected from respondents choosing more than one of the race categories have not yet been issued. The full text of the OMB Federal Register notice is available on line at http:// www.whitehouse.gov/WH/EOP/ OMB/html/fedreg.html.

\section{Affirmative Action Bans Have Unclear Impact on Minority Admissions}

A Science magazine survey of graduate admissions to a select group of science, engineering, and medical programs (Barringa 1997, $633-34)^{1}$, indicates that the effects of the two states' recently enacted bans on affirmative action by California and Texas have not had a clearly uniform negative impact.

While admissions of black and Hispanic students to most large, competitive programs at universities in both states have dropped, a number of the smaller programs registered smaller decreases. For instance, while none of the 14 African 